\title{
Status Poligami \\ Dalam Perundang-Undangan Konvensional dan Kontemporer Serta Relevansinya Dengan Surat An-Nisa' Ayat 3
}

\author{
Ahmad Furqon Darajat \\ (STIS Darul Falah Pagutan Mataram, addaraja87@gmail.com)
}

\begin{abstract}
Abstrak
Persoalan poligami tetaplah menjadi krusial dari masa ke masa. Jelas sana karena dalam praktik poligami masih menyisakan pekerjaan rumah yang belum selesai dari dulu. Kerap saja dalam praktik poligami ada pihak yang diuntungkan dan pihak yang dirugikan. Sebab itulah dalam kajian deskriptif ini akan diteluri aspek legal formalnya untuk dicari relevansinya dengan kajian normatif pada ayat alqur'an yang dianggap telah melegitimasi terjadinya diskriminasi tersebut. (The issue of polygamy remains crucial from time to time. Obviously there, because in practice polygamy still leaves homework unfinished. Often in the practice of polygamy there are those who benefit and those who are disadvantaged. That is why in this descriptive study formal legal aspects will be explored to look for relevance to the normative study of the verse in the Qur'an which is considered to have legitimized the occurrence of such discrimination.)
\end{abstract}

\section{Kata Kunci:}

Poligami, Konvensional, Kontemporer, An-Nisa' Ayat 3

\section{Pendahuluan}

Perkawinan adalah ikatan antara pria dan wanita yang kokoh (mitsakon gholidzon) dengan tujuan mentaati perintah Allah dan melaksanakannya merupakan ibadah yang bertujuan mewujudkan 
Status Poligami Dalam Perundang-Undangan Konvensional dan Kontemporer Serta Relevansinya Dengan Surat An-Nisa' Ayat 3

kehidupan rumah tangga yang sakinah mawaddah wa rahmah ${ }^{1}$. Perkawinan menjadikan seseorang terjaga dari perbuatan yang keji dan mungkar yakni menjaga pandangan dan kemaluan mereka². Hubungan antara pria dan wanita ini pula menjadi sarana memberlangsungkan kehidupan umat manusia. Sehingga di dalam Literatur keislaman, ushul fiqh, telah menjadi sebuah asas dalam proses pembentukan hukum Islam yakni menjaga keturunan (hifz an nasl).

Dalam literatur fiqh Islam konvensional, perkawinan masuk dalam bidang muamalah karena terkait dengan hubungan integral manusia. muamalah menyangkut pola hubungan horizontal antar manusia yang meliputi perdagangan, politik, perkawinan, pewarisan,pidana dan lainnya. Karena sifatnya yang horizontal ini, maka ia boleh di interpretasikan dalam arti bebas dari pandangan sakralitas seperti pada ajaran-ajaran horizontal yakni ibadah. Akan tetapi kenyataan dilapangan seringkali terjadi hal yang bertolak belakang, karena muammalah mempunyai tingkat sama dengan ibadah sehingga menjadi sebuah ajaran yang sakral dan mutlak. Dan tidak memungkinkan di ganggu gugat.

Umpamanya dalam perkawinan nash-nash poligami seringkali menjadi sesuatu ajaran yang nampak absah. Sehingga sudah pasti kemudian pihak yang tidak diuntungkan adalah perempuan. Persoalan krusial inilah yang menjadi beban kaum perempuan sepanjang zaman. Mereka terpaksa harus rela menjadi korban superioritas laki-laki. Sebenarnya datangnya Islam menjadi angin segar terwujudnya emansipasi dengan laki-laki, namun produk hukum fiqh justru tampil intoleran serta menjadi doktrin yang membelenggu terutama dalam menyikapi perkembangan dunia yang menghendaki kesetaraan kedudukan.

Rumusan-rumusan fiqh tersebut kenyataannya tidak pernah mengalami distorsi paradigma yang signifikan dan bahkan cenderung mangadopsi pemikiran-pemikiran kaum pra Islam, yakni menganggap perempuan sebagai makhluk pinggiran, pemuas nafsu.

\footnotetext{
1 Kompilasi Hukum Islam Pasal 2 dan 3

2 Sebagaimana Sabda Rasulullah S.A.W yang diriwayatkan Imam Bukhari

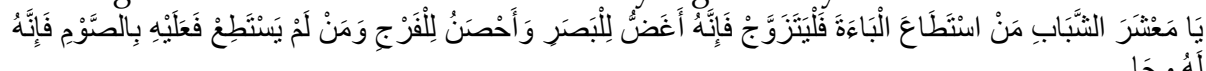


Hak-hak kemanusiaan (humanities) yang dijamin Islam tidak pernah seimbang, dan hanya sedikit yang terartikulasi dalam kehidupan mereka didunia. Padahal Islam datang kepada umat manusia dalam konteks menciptakan keadilan terlebih keadilan sosial dan ekonomi³.

Oleh karena itu, posisi mereka dalam agama Islam memang harus senantiasa berkiblat kepada pria, baik itu kepada wali maupun suami. Doktrin kepasrahan ${ }^{4}$ atas mereka ini rupanya menjadi jalan melegitimasi perbuatan-perbuatan seperti halnya poligami, pembagian waris yang sepihak, serta pemaksaan perkawinan. Sehingga bisa dipastikan perempuan pasti akan selalu menjadi korban (victim) secara fisik maupun psikologis laki-laki ${ }^{5}$. Apalagi pada poligami meskipun nash Al-Qur'an memberi peluang, namun bukan lantas dapat dilakukan secara sembarangan.

Poligami merupakan salah satu Isu sentral yang sering dikemukakan para penggiat gender selain emansipasi wanita. Bahkan Poligami mendapatkan tempat khusus disebabkan perilaku ini tidak mencerminkan penghargaan terhadap wanita yang sejak lampau memang senantiasa berada dibawah laki-laki (Arrijaalu Qowwamuna 'Alan Nisaaa'). Ketidak puasaan ini pulalah yang memaksa mereka untuk menyuarakan reformasi kelembagaan dalam masyarakat terlebih agama, agar agama tampak egaliter dan dapat menyesuaikan diri dengan perkembangan zaman dan peradaban umat manusia.

Tulisan ini hanya menjelaskan konsepsi poligami yang berasal dari beberapa teori yang tengah berkembang secara umum. Dan tulisan ini mencoba melacak secara historis asal muasal praktek poligami yang dilegalkan oleh beberapa ulama.

\section{Pemikiran Poligami Islam Konvensional}

Poligami merupakan gejala sosial dan masalah masyarakat yang sangat klasik. Sebelum Islam, poligami telah membudaya pada setiap

${ }^{3}$ Fazlur Rahman, Islam dan modernity transformation of an intellectual tradition, (Chicago, Chicago press, 1984), hal. 13

${ }^{4}$ Karena doktrin taqlid perempuan terhadap wali ini menjadi syarat sah suatu perkawinan,. Lihat selengkapnya As-Sayrazi, Al- Muhazzab, (Darul Ihya, 1994), Juz.II, Bab. Nikah, hal. 45

5 Haedar Nasir, Islam dan kontekstualisasi seksualitas, (yogyakarta, Pustaka Pelajar, 2002), hal.78 
Status Poligami Dalam Perundang-Undangan Konvensional dan Kontemporer Serta Relevansinya Dengan Surat An-Nisa' Ayat 3

peradaban dan generasi umat manusia. Misalnya saja bangsa Isra'il, Persia, Arab, Romawi, bahkan bangsa Babilonia, meskipun dengan cara yang berbeda antara satu dengan yang lain. Status wanita di hampir semua generasi pada masa itu memojokan dan menghinakan posisi wanita dalam posisi terendah serta tidak lebih sebagai pelayan, tukang melahirkan anak, apalagi ketika haid (menstruasi) wanita harus diasingkan di gubuk-gubuk di luar daerah yang jauh dari pemukiman dan keluarga karena dianggap kotor dan sumber malapetaka6. Karena itulah wanita hanya pantas sebagai selir dan gundik bagi laki-laki.

Situasi pasca datangnya Islam merupakan tonggak baru lahirnya penghargaan terhadap wanita. Terkait dengan itu Islam memperhatikan sekali problematika para wanita dalam hak-hak mereka. Agama Islam melalui konsep universal Al-Qur'an menetapkan beberapa aturan perihal keberadaan wanita. Apalagi dalam kaitan kehidupan mereka dalam rumah tangga. Khusus dalam poligami Al-Qur'an dalam hal ini dijadikan rujukan oleh para ulama surat An-Nisa ayat 3.

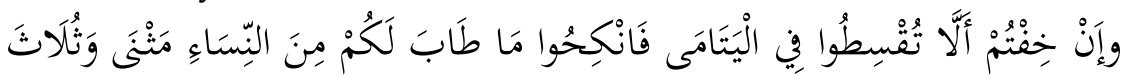

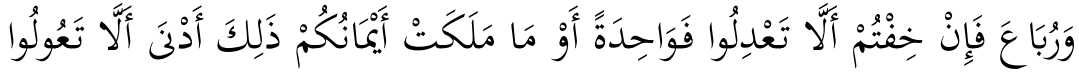

"Dan jika kamu takut tidak akan dapat berlaku adil terhadap (hak-hak) perempuan yang yatim (bilamana kamu mengawininya), maka kawinilah wanita-wanita (lain) yang kamu senangi : dua, tiga atau empat. Kemudian jika kamu takut tidak akan dapat berlaku adil, maka (kawinilah) seorang saja, atau budak-budak yang kamu miliki. Yang demikian itu adalah lebih dekat kepada tidak berbuat aniaya."

Para ulama ahli Tafsir hampir seluruhnya mentakwil ayat di atas dengan kebiasaan-kebiasaan bangsa Arab Jahiliyah dahulu, yakni mengenai penguasaan mutlak atas anak yatim yang sedang mereka ampu. Terhadap anak yang diampu, mereka boleh mengawini atau menolak pinangan dari siapapun yang menginginkan anak yatim

6 Nasaruddin umar, Islam dan kontekstualisasi seksualitas, (yogyakarta, Pustaka Pelajar, 2002), hal.37

7 Fadlurrahman, Islam Mengangkat Martabat Wanita, (Gresik, Putra Pelajar, 1999), hal.29-46 
menjadi istri. Lantaran perbuatan tersebut, hak-hak anak yatim hilang, apalagi dengan adanya harta peninggalan yang berlebih setelah mereka dinikahi, maka seluruhnya menjadi milik wali tersebut. khawatir anak yatim tersebut terlantar dan terzolimi pasca perkawinan yakni dengan tidak adanya keadilan atas mereka, Allah kemudian menganjurkan para wali ini menikahi perempuan lain yang mereka sukai. Lebih lanjut konsep keadilan dalam akhir surat tersebut ditujukan kepada para wali karena pada masyarakat arab lampau mengawini anak yatim senantiasa tidak disertai dengan adanya keadilan dalam memberi nafkah kepada mereka. ${ }^{8}$

Poligami sendiri merupakan suatu kebiasaan yang telah mengakar dalam kehidupan bangsa Arab bahkan pada masa pra Islam. Ketika Islam datang kebiasaan ini oleh para ulama Islam dalam fatwa hukumnya terlihat hanya menegaskan status dan tradisi yang telah hidup sebelumnya. Tanpa ada reformulasi kembali sehingga inilah yang memunculkan stigma negatif terhadap poligami meskipun terbingkai dalam ajaran agama.

Walaupun sisi historis ayat yang tersebut tidak berbicara masalah poliami secara mutlak. Disamping itu juga pemahaman literal yang tidak utuh atas sebuah tema dan terkesan tercampur aduk (mixed) dalam teks-teks keagamaan meruncingkan pula perbedaanperbedaan lainnya9', seperti dalam jumlah istri yang boleh di poligami ${ }^{10}$. Sehingga ini menambah kesan inhumanisme Islam dalam memandang status wanita sebagai bagian integral dalam kehidupan manusia (Min Nafsin Waahidah) ${ }^{11}$.

${ }^{8}$ Lihat Tafsir At-Thobari, Tafsir Ibnu Katsir, Tafsir Jalalin, atau bahkan Tafsir Al-Manar dalam menafsirkan Surat An-Nisa Ayat 3.

9 Khairuddin Nasution, Status Wanita di Asia Tenggara: studi terhadap perundang-undangan perkawinan indonesia dan malaysia, ( Jakarta, Inis, 2002 ), hal. 287-290.

10 Mengenai jumlah istri yang boleh dipoligami para ulama fiqh konvensional terdapat khilaf: diantaranya ada yang boleh empat, delapan, sembilan, dua puluh sembilan dan bahkan lebih. Perbedaan timbul dalam

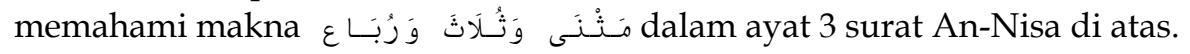
11 Surat An-Nisa Ayat. 1 
Status Poligami Dalam Perundang-Undangan Konvensional dan Kontemporer Serta Relevansinya Dengan Surat An-Nisa' Ayat 3

Para ulama mazhab yakni kalangan Mazhab Hanafi, dalam kitab Al-Mabsut ${ }^{2}$, menerangkan kebolehan poligami serta kewajiban suami berlaku adil dalam memberi nafkah terhadap para istri. Kewajiban ini berangkat dari pemahaman ayat Al-Qur'an terutama surat An-Nisa ayat 3 serta beberapa hadits ancaman anggota badan yang miring kelak di akhirat terhadap suami yang tidak berlaku adil $^{13}$. Kewajiban berlaku adil karena menyangkut status suami (azzauj) sebagai pemimpin ( $r a^{\prime}$ in). Implikasi keadilan demikian lalu dihubungkan dengan hadits rasulullah tentang kepemimpinan ${ }^{14}$. Meskipun demikian konteks adil ialah hanya dalam pemahaman yang zahir meliputi uang belanja sampai kebutuhan sexs, tidak pada yang batiniyah, rasa cinta $^{15}$. Imam As-Shona'i lebih lanjut menjelaskan jumlah maksimal istri yang boleh dipoligami adalah empat ${ }^{16}$.

Imam Malik bin Anas dalam Mudawwanah kubro menyebutkan pula kebolehan memperistri wanita hingga empat. Dalam karya tersebut Imam malik tidak secara jelas mengungkap dalil yang berasal dari Al-Qur'an. Namun adanya kisah-kisah dalam hadis yang menceritakan seseorang kafir Harbi- Redaksi kitab Al-Muwatto' mengisahkan seseorang dari Bani Tsaqif- yang masuk Islam, sedangkan memiliki sepuluh istri lalu menceraikan enam orang istri

12 Selanjutnya hal ini diperkuat dengan akhir ayat surat An-Nisa ayat 3, serta أن النبي كان يعدل في الفسمة بين نسائه وكان يقول hadits nabi yang diriwayatkan A'isyah اللهم هذا قسمي فيما أملك فلا تؤاخذني فيما لا أملك يعني من زيادة المحبة لبعضهن giliran (qismah) hendaknya diutamakan istri tua karena membawa kehormatan keluarga karena pengabdiannya, dibandingkan istri muda. Syamsudin as Syarakhsi, Al- Mabsut, (Beirut, Darul kutub Alamiyah, 1993), juz VI, hal. 217

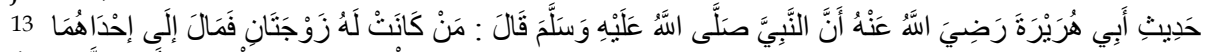

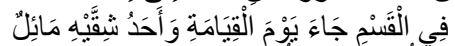

14 Sعetiap kalian adalah pemimpin, kemudian setiap pemimpin kelak ditanya atas kepemimpinanya)

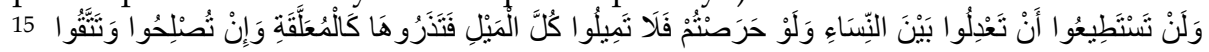

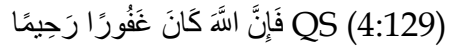

16 As-Shona'i, Bada'i as Shona'i, (Beirut, Darul Kutub Al-Araby, 1996), Juz 2, hal. 394 
dan menyisakan empat orang17. Dalam keadilan terhadap para istri ialah hanya dalam hal-hal yang zahir. Kemudian keharaman bersenang-senang dengan Istri yang terzolimi disebabkan ketidaksamaan atau bahkan kecondongan kepada istri lain- karena lebih cantik dari yang lain- dalam memberi nafkah tersebut. ${ }^{18}$

Dalam Al-Umm diterangkan pula tentang kebolehan poligami yang dibatasi hingga empat. Kebolehan diambil dari pemahaman ayat Al-Qur'an surat An-Nisa ayat 3 serta hadits yang menceritakan seorang laki-laki Gilan Bin Salamah serta Naufal bin Muawwiyah yang baru masuk Islam sedangkan mereka memiliki lebih dari seorang istri, kemudian oleh rasul diperintah mempertahankan empat. Beliau (imam as-syafi'i) sendiri meragukan kandungan hadits tersebut. Pengarang Al-Umm menemukan adanya pertentangan dalam konten hadits ${ }^{19}$. Imam As-Syafi'i dalam karya ini menegaskan pula secara mutlak batasan menambah istri maksimal empat. Adapun sebaliknya yakni melebihi empat, maka mutlak keharamannya. ${ }^{20}$

Dengan tujuan intensitas kedekatan yang sangat antara suami dan istri, kalangan mazhab Hambali memperbolehkan poligami maksimal empat. Menurut mereka ayat 3 Surat An-Nisa menghendaki pemilihan dalam poligami yakni dua, tiga, atau empat. Lebih lanjut menurut mereka, apabila dianjurkan memilih status jumlah istri dalam poligami, maka mereka akan condong kepada pemahaman An-Nisa yakni yang hanya menganjurkan dua saja, atau

17 Malik bin Annas, Mudawwanah Al Kubro ,(tt,tp,tt), hal. 202 dan 310, lihat pula kitab Al-Muwatto'.

18 Abdurrahman Al-Jaziri, Al-Figh A'la Mazahib Al-Arba'ah, (tt.tt.tt), juz. IV, hal. 210

19 Tampaknya Imam As-syafi'i sedikit ragu dengan hadits kebolehan poligami hingga empat. kisah Gilan bin Salamah As syaqofi menceritakan rasulullah menyuruhnya menceraikan enam istri setelah sebelum masuk islam memeiliki 10 orang istri, lalu kisah Naufal bin Muawwiyah yang memiliki 5 orang istri dan oleh beliau diperintah untuk mempertahankan 4 dan menceraikan satu orang. Sedangkan dalam riwayat yang berbeda perihal kisah Naufal bin Muawwiyah, menceritakan setelah masuk Islamnya dia memiliki dua orang perempuan bersaudara yang sedang dinikahinya. Lalu oleh rasulullah disuruh memilih hanya salah satu dari mereka yang paling dicintainya.

${ }^{20}$ Muhammd Idris As-Syafi' i, Al-Umm, (tt,tt,tt), Juz 5, hal. 155 
Status Poligami Dalam Perundang-Undangan Konvensional dan Kontemporer Serta Relevansinya Dengan Surat An-Nisa' Ayat 3

tiga saja atau empat, dibandingkan pemahaman kisah tentang riwayat Gilan Bin Salamah serta kisah Naufal bin Muawwiyah yang mereka anggap tidak memberikan pemilihan, sehingga tampak poligami secara luas dan langsung diperbolehkan hingga empat. disamping ada pula berpendapat hingga sembilan atau delapan belas. Namun terakhir ini dikatakan menyimpang dari ijma'(Kharqun lil ijma' ) dan bahkan para ulama yang memberi pendapat seperti demikian dianggap tidak mampu berbahasa arab21.

Ulama Islam konvensional dari kalangan mazahib Imam Hanafi, Maliki, Syafi'i, dan Hambali semuanya menyepakati tentang kebolehan poligami. Hanya saja para ulama tidak ada perbedaan bahwa kebolehan sejatinya hingga empat. Dalil yang mereka sepakati bersumber pada Al-Qur'an surat An-Nisa ayat 3. Sedangkan dasar hadits, banyak mempergunakan riwayat Gilan bin Salamah dan Naufal Bin Muawwiyah yang ketika itu memiliki istri lebih dari seorang, kemudian oleh Rasulullah diperintah untuk mempertahankan empat serta menceraikan sisanya. Sedangkan dalam masalah keadilan yang menjadi perdebatan dalam poligami ini, mereka seluruhnya sepakat bahwa keadilan yang dimaksud adalah keadilan dalam memberikan nafkah yang zahir -bukan keadilan dalam cinta. sehingga memberikan efek, poligami dapat dilakukan sejauh hak-hak yang meliputi sandang, pangan dan papan si calon istri terpenuhi, apalagi dengan dalih sesuai dengan tujuan Islam sendiri yakni mengangkat derajat perempuan yang nyata-nyata rendah di masa lampau.

Ulama-ulama lain pengusung semangat kontemporer serta humanis semisal Muhammad Abduh, Rasyid Ridha nyata-nyata menganggap poligami tidak layak diaplikasikan dalam kehidupan umat Islam saat Ini, akan tetapi mereka masih mentolerir apabila karena tuntutan yang mendesak, dengan tujuan kemaslahatan. Dalam hal ini poligami dianggap rukhsah. Mereka berpatokan pada kondisi masyarakat Islam pada masa awal Islam, sedangkan Rasulullah saat itu sedang mulai membangun peradaban dan belum sepenuhnya dapat melepaskan belenggu tradisi arab secara sepenuhnya. Saat itu poligami boleh karena wanita dapat sejahtera, terpenuhi dan terhormat penghidupannya. Namun apabila poligami

${ }^{21}$ Ibnu Qudamah, Al-Mugni, (tt,tt, tt) Juz 5, Hal. 42 
oleh pria pada zaman sekarang -tanpa ada kebutuhan mendesakmaka itu hanya bertendensi mengkuti hawa nafsu. ${ }^{22}$

Kemudian pasca Islam berkuasa di tanah Arab poligami juga menjadi alternatif bagi perempuan yang kehilangan suami ketika peperangan. Dengan adanya poligami para janda dapat terpenuhi segala kebutuhannya karena ada suami kedua yang mengganti suami pertama yang gugur dalam peperangan. Karena alasan inilah poligami pada masa itu oleh Islam dipandang sangat bermanfaat dalam kehidupan keluarga. Sehingga pada masa sekarang dimana umat islam tidak mengalami hal diatas maka poligami tidak layak dilakukan, bahkan lebih lanjut menurut mereka konsep monogami yang paling layak menjadi asas dalam perkawinan dalam Islam.

Pemahaman semantik surat An-Nisa ayat 3 setelah dikontekstualisasi dengan Asbabun Nuzul sejatinya tidak mencerminkan kebolehan poligami secara luas, namun secara khusus (khos) ditujukan kepada orang tertentu, dan semestinya berlaku mutlak hanya kepada wali serta kepada Rasulullah dengan 8 orang istrinya ${ }^{23}$. Sekali lagi menurut mereka poligami bertentangan dengan hukum asli serta meniadakan ketentraman, ketenangan jiwa, serta kasih-sayang yang menjadi rukun wajib dalam kehidupan berumah tangga. ${ }^{24}$

Jika mencermati dalil-dalil yang dikemukakan. Perihal kebolehan ini ulama terpecah menjadi dua kubu (1) Azimah dan (2) Rukhsah. Azimah karena kebolehan tersebut adalah mutlak tanpa dibatasi apapun termasuk sifat adil. Mereka memahami ayat tersebut secara mutlak, disebabkan ayat ini berdiri sendiri dan tidak ada qayyid baik dari Al-Qur'an maupun hadits. Menurut mereka kisah seorang Bani Tsaqif didalam hadis berbeda konteks dengan pemahaman ayat Al-Qur'an. Juga karena hadits tersebut diperselisihkan oleh para ahli hadits. Sedangkan kebolehan karena Rukhsah dipahami karena adanya darurat, serta qayyid kewajiban

22 Muhammad Rasyid bin Ali Ridha, Tafsir Al-Manar, (mesir: 2002), Juz IV, hal. 357-358.

${ }^{23}$ Abdul Wahab Khalaf, Ilmu Ushul Figh, (Indonesia, Haromain, 2003), hal.191

${ }^{24}$ Muhammad Rasyid Ridha, Op.Cit, Hal.369 - 370. 
Status Poligami Dalam Perundang-Undangan Konvensional dan Kontemporer Serta Relevansinya Dengan Surat An-Nisa' Ayat 3

berlaku adil. jadi apabila tidak karena darurat serta tidak akan mampu berbuat adil maka hukum poligami adalah haram ${ }^{25}$.

Ditengah perbedaan pendapat di antara para ulama diatas, satu yang dapat digaris bawahi bahwa poligami dalam pemahaman ulama diatas masih diperbolehkan keberadaannya. ini mengacu pada Nash Al-Qur'an khususnya surat An-Nisa yang mengandung Isyarat ajaran yang terkait Poligami. Dan barangkali apa yang dikatakan AzZuhaili tepat bahwa pada dasarnya poligami itu tidak dianjurkan dalam syari'at kecuali ada beberapa sebab mendesak. Dengan kata lain dianjurkan namun masih memandang beberapa ketentuanketentuan serta beberapa prasyarat ${ }^{26}$. Terlepas dari itu semua, poligami dalam Islam setidaknya memiliki aspek positif terutama bagi perempuan, apabila kita analisa kedudukan perempuan dalam konteks sejarah kehidupan umat manusia.

1. Poligami dalam Islam memperbaiki derajat kaum wanita yang pada masa lalu, khususnya Arab Jahiliyah yang dilakukan sewenang-wenang serta tidak terbatas. Poligami dalam Islam memberi serta menghormati hak-hak mereka kembali sebagai wanita.

2. Poligami dalam Islam mencegah kekecewaan suami yang akan mengakibatkan perceraian disebabkan istri yang mandul, cacat, atau lumpuh.

3. Banyaknya Janda korban perang di zaman Rasulullah. Tanpa poligami dikhawatirkan akan terjadi hubungan ilegal dengan laki-laki lain sehingga melanggar hukum-hukum agama.

4. Mencegah agresifitas nafsu suami dikala istri sedang haid atau pasca melahirkan. ${ }^{27}$

\section{Pemikiran Poligami Kontemporer}

Poligami dalam pandangan pemikir Islam kontemporer mayoritas menolak keberadaannya kecuali dalam keadaan yang

25 Ibrahim Hosen, Figh Perbandingan Masalah Pernikahan, (Jakarta, Pustaka Firdaus, 2003), hal.144-152

${ }^{26}$ Wahbah Az-Zuhaili, Fiqh Islam Wa Adillatuhu, (Beirut, Darul Fikr, 1985 ), Juz VII, hal.169

27 Ibid, hal. 138-140. 
sangat mendesak. Dalam merumuskan pemikiran tersebut mereka menggunakan pendekatan-pendekatan ilmu-ilmu sosial yang melihat konteks sosial empirik sebagai acuannya.

Berangkat dari tujuan perkawinan yakni membentuk rumah tangga sakinah, mawaddah, warahmah, Tahir Al- Haddad menyatakan poligami merupakan perbuatan yang harus dicegah. Menurutnya, kenyataan di lapangan menunjukan poligami sulit menciptakan keharmonisan dalam rumah tangga yakni antara suami, para istri dan anak-anak mereka. Bahkan pasca wafat suami ketika harta warisan yang ditinggalkan sangat minim. Poligami tandasnya memang bertujuan baik untuk membina hubungan yang harmonis serta menambah keturunan yang soleh, namun keadaan demikian hanya ditemukan pada perilaku Rasulullah, oleh karena itu poligami hanya berlaku (khos) terhadap beliau bukan umatnya, apalagi poligami Rasulullah terjadi sebelum turunnya dalil-dalil tahdid (pembatasan) ${ }^{28}$.

Fazlur Rahman menyatakan perlunya pembahasan yang menyeluruh (holistik) terhadap poligami. pembahasan ini bertujuan guna menemukan topik sentral poligami. Menurutnya dalil poligami yang didalilkan para ulama konvensional bersifat temporer, yakni hanya berlaku pada konteks sosial Rasulullah saat itu. Oleh karenanya, apabila kebutuhan poligami ingin terwujud pada masa ini, haruslah ditemukan sebuah indikasi kuat yang dipahami dari topik sentral tersebut melalui kajian yang menyeluruh (holistik). ${ }^{29}$

Pemikiran senada juga datang dari Ashgar Ali Enginer. Menguatkan pendapat Fazlur Rahman, ia menekankan pentingnya pemahaman konteks turunnya ayat secara menyeluruh. Menurutnya konteks ayat 3 surat An-Nisa menggambarkan orang yang aniaya terhadap tanggung jawabnya memelihara anak yatim. Menurutnya pula, turunnya ayat poligami ini pasca terjadinya peperangan uhud dimana sebanyak 70 orang mujahidin gugur yang mengakibatkan banyak istri yang menjanda. Jadi secara konteks ayat tersebut mengindikasikan pertolongan. Walaupun Ashgar menyatakan demikian, namun ia masih membolehkan poligami karena ada sebab

\footnotetext{
${ }^{28}$ Khairuddin Nasution, op.cit. 128-130
}

${ }^{29}$ Khairuddin Nasution, op.cit. 130 
Status Poligami Dalam Perundang-Undangan Konvensional dan Kontemporer Serta Relevansinya Dengan Surat An-Nisa' Ayat 3

mendesak dan tidak berlaku umum seperti yang banyak dipraktekan hingga saat ini. 30

Pemikir sekaligus aktivis kewanitaan dari Amerika Amina Wadud Muhsin secara mutlak menolak poligami bahkan dengan alasan apapun. Menurutnya perkembangan kehidupan umat manusia saat ini -khususnya wanita- tidak lagi hanya bertumpu pada kepentingan finansial yang kemudian menjadi titik tekan dalam pembahasan ayat An-Nisa ayat 3 tentang keadilan material. kemudian dalam problematika kemandulan, hal itu dapat diatasi dengan cara mengangkat anak. Kebahagiaan sebagai tujuan dalam perkawinan tidak akan terwujud apabila harus dibagi dengan sekian banyak istri, jadi poligami menegasikan "ketentraman" dan "cinta kasih" dalam rumah tangga. Pendekatan hermeneutik yang dipergunakannya sekali-lagi menegaskan bahwa poligami itu identik dengan pemuasan hasrat seksual, sehingga secara mutlak haram karena tidak sesuai dengan Al-Qur'an. ${ }^{31}$

\section{Konsep Poligami Dalam Perundang-Undangan}

1. Indonesia

Undang-undang Perkawinan No 1 tahun 1974 menegaskan sejatinya seorang pria hanya boleh memiliki seorang istri ${ }^{32}$. Ketentuan ini dapat berubah apabila pihak-pihak tertentu menghendaki lebih dari satu, namun tetap dengan izin pengadilan ${ }^{33}$, dengan bentuk tertulis ${ }^{34}$. Kebolehan demikian mempertimbangkan beberapa sebab diantaranya, (1) Istri tidak dapat menjalankan kewajibannya, (2) Istri memiliki cacat atau penyakit yang mustahil disembuhkan, dan (3) istri tidak dapat melahirkan keturunan ${ }^{35}$. Kompilasi Hukum Islam menambahkan bahwa batas maksimal suami melakukan poligami adalah empat orang istri ${ }^{36}$. Dengan syarat suami harus mampu berlaku adil

\footnotetext{
${ }^{30}$ Khairuddin Nasution, op.cit. 132-134

${ }^{31}$ Khairuddin Nasution, op.cit. 134-135

32 Undang- Undang Perkawinan No.1 tahun 1974 Pasal 2 ayat 2.

33 Undang- Undang Perkawinan No.1 tahun 1974 Pasal 2 ayat 3.

34 Peraturan Pemerintah No. 9 Tahun 1975 Pasal 40

35 Undang- Undang Perkawinan No.1 tahun 1974 Pasal 4 ayat 2

36 Kompilasi Hukum Islam, pasal 55 ayat 1
} 
terhadap para istri dan anak-anaknya ${ }^{37}$. Kewajiban berlaku adil terhadap mereka merupakan syarat yang memberatkan, sehingga apabila tidak mampu memenuhinya, maka secara otomatis dilarang secara hukum ${ }^{38}$.

2. Turki

Undang-undang perkawinan Turki melarang poligami saat suami masih menjalin perkawinan dengan istri pertama. Menurut UU Turki perkawinan kedua harus membuktikan kepada pengadilan bahwa sedang tidak menikah yakni dengan akte perceraian, akte batalnya perkawinan, atau akte kematian istri. Sehingga perkawinan kedua adalah sah ketika pria bebas dari ikatan dengan istri pertama. Alasan pelarangan poligami dalam perundang-undangan Turki karena mereka menganggap bahwa praktek monogami adalah usaha perbaikan praktek poligami pada bangsa arab pra Islam yang berlaku sewenang-wenang, disamping status sosial masyarakt turki yang dipengaruhi ideologi sekuler. ${ }^{39}$

3. Yaman selatan

Hukum keluarga di yaman memperbolehkkan praktek Poligami namun dengan beberapa batasan. Pengadilan memperbolehkan poligami setelah sebelumnya memperoleh izin tertulis, dengan alasan (1) Istri mengalami kemandulan yang dikuatkan dengan keterangan dokter, (2) Istri menderita penyakit kronis yang kiranya mustahil sembuh, yang apabila tidak berpoligami akan mengganggu keberlangsungan kehidupan rumah tangga. Poligami disini sejatinya ditujukan untuk menjaga keberlangsungan perkawinan, bukan karena memperhatikan kemampuan suami untuk berlaku adil. ${ }^{40}$

37 Kompilasi Hukum Islam, pasal 55 ayat 2

38 Kompilasi Hukum Islam, pasal 55 ayat 3

39 Atho Muzhar, Hukum Keluarga Di Dunia Islam Modern,(Jakarta:ciputat press:2003), hal.44-45

${ }^{40} \mathrm{Ibid}, 74-75$ 
Status Poligami Dalam Perundang-Undangan Konvensional dan Kontemporer Serta Relevansinya Dengan Surat An-Nisa' Ayat 3

\section{Tunisia}

Poligami di Tunisia menurut undang-undang hukum keluarga pasal 18 dilarang secara mutlak dan bahkan yang melakukannya sedangkan masih dalam status perkawinan akan memperoleh hukuman penjara serta denda. Menurut Jhon L. Esposito larangan poligami karena menganggap poligami sebagai bentuk lain perbudakan yang selamanya tidak pernah diterima manusia siapapun dan dimanapun. Selanjutnya bahwa sistem perkawinan ideal menurut Al-Qur'an adalah monogami. Pemerintah Tunisia dalam merumuskan aturan tersebut banyak dipengaruhi pemikiran Muhammad Abduh yang menyatakan bahwa konsep Poligami sudah dengan sendirinya dibatasi AlQur'an, sehingga idealnya adalah Monogami. Lebih lanjut dikatakan konsep adil adalah konsep yang sulit diaplikasikan dalam kehidupan rumah tangga, sehingga akan sangat sulit diaplikasikan secara utuh. ${ }^{41}$

\section{Maroko}

Menurut undang-undang keluarga negara maroko, poligami boleh dilakukan. Undang-undang negara maroko membuat semacam aturan serta peringatan yakni poligami hanya dapat dilakukan apabila suami merasa mampu melakukannya sehingga negasinya, poligami tidak dilakukan jika tidak terdapat kemampuan dalam berlaku adil. Meskipun pernyataan pasal ini bertujuan membatasi praktek poligami serta melindungi hak-hak perempuan, namun menjadi lemah karena ketidaktegasan serta ketiadaan indikator keadilan yang menjadi konsensus bersama sehingga kemampuan berlaku adil hanya berdasarkan asumsi personal belaka. Selain itu praktek poligami diatur undangundang Maroko (1) Jika seseorang ingin berpoligami maka harus memberitahukan kepada calon istri tentang status perkawinannya. (2) Bolehnya calon Istri mencantumkan taklik talak dalam akad nikah. (3) meskipun istri tidak mencantumkan taklik talak dalam akad nikah lalu dikemudian hari ditemukan masalah yang menyebabkan istri kedua menderita, maka pengadilan dapat

${ }^{41}$ Ibid, 88-89 
membubarkan serta memutus hubungan perkawinan secara sepihak. ${ }^{42}$

Demikian pula praktek poligami di negara-negara lain semisal Aljazair, Afghanistan, dan somalia. Poligami telah disahkan perundang-undangan dinegara tersebut. Pengesahan tersebut dengan melalui beberapa persyaratan yang ketat, yakni apabila ditemukannya indikasi-indikasi yang memperbolehkan seperti kemandulan, penyakit parah yang diderita istri. Itu semua semata-mata bertujuan melindungi hak-hak perempuan serta menekan pemberlakuan poligami secara luas yang telah terlegitimasi serta mewujudkan kehidupan rumah tangga yang sakinah, mawaddah warahmah.

\section{Poligami dalam Surat An-Nisa Ayat 3}

Status Poligami perspektif Islam, yakni dalam upaya pemahaman dalil pokok surat An-Nisa Ayat 3 menimbulkan perbedaan pemahaman diantara para Ahli Islam. Para ulama konvensional yang berpedoman kepada pemahaman yang sederhana terhadap teks (semantik) secara luas memperbolehkan mengaplikasikan poligami kepada masyarakat, akan tetapi dengan beberapa catatan. Hal ini mengindikasikan mereka tetap berhati-hati terhadapnya. .Meskipun pemahaman secara teks dan konteks dalam ayat rujukan tersebut berbeda.

Secara positif kebolehan secara luas ini bertujuan melindungi hak-hak perempuan terlebih dalam usaha menjaga kehormatan agama (hifz addiin). Disertai dengan pembatasan jumlah yang memang memperketat poligami yang pernah terjadi pada masa pra Islam secara sewenang-wenang.

Para pemikir kontemporer dengan seperangkat metode ilmiyah pada dasarnya tidak membuahkan suatu pemikiran baru terhadap poligami, kecuali mereka yang memang tidak menggunakan sama sekali piranti agama dalam memahami ayat tersebut. Poligami menurut mereka di sini hanyalah bersifat normatif yakni menguatkan status monogami dengan memperketat syarat-syarat serta memberlakukannya secara tertentu atau khusus berdasarkan argumen-argumen yang logis dan poligami diperbolehkan jika ada

42 Ibid, $110-111$ 
Status Poligami Dalam Perundang-Undangan Konvensional dan Kontemporer Serta Relevansinya Dengan Surat An-Nisa' Ayat 3

kebutuhan yang sangat mendesak yang apabila tidak dilakukan akan menghancurkan keutuhan mahligai rumah tangga.

Kemudian dalam aplikasi pembaharuan hukum keluarga khususnya poligami dalam beberapa negara Islam, sejatinya telah menghasilkan undang-undang yang mengakomodir dan melindungi hak-hak perempuan. Ini terbukti dengan bentuk undang-undang yang telah mampu mengadopsi pemikiran ulama konvensional serta kontemporer, yang terwujud -hampir mayoritas undang-undang negara muslim- dalam pemberlakuan poligami secara khusus, yakni diperbolehkan poligami hanya dalam beberapa kasus yang mendesak.

Oleh karena itu status poligami yang berlaku di negara-negara Islam atau umat muslim secara keseluruhan terbagi kedalam tiga pembagian besar :

1. Boleh secara mutlak

Kebolehan disini berdasarkan nash-nash Al-Qur'an khususnya surat An-nisa ayat 3 dan diperkuat dengan beberapa ketentuanketentuan dari hadits. disini ayat tersebut diamalkan secara normatif. Pengamalan disini berdasarkan konsep azimah yang memang dipahami para ulama dari ayat tersebut.

2. Boleh dengan syarat

Pengamalan demikian masih memperhatikan konteks yang tengah berlaku di masyarakat. Juga kerena pemahaman poligami pada ayat itu adalah sebagai rukhsah sehingga akan berlaku jikalau terdapat beberapa masyaqat atau keadaan yang membuatnya harus dilakukan, seperti kemandulan pada istri hingga penyakit yang membuatnya tidak mampu melayani suami dengan baik.

3. Tidak boleh secara mutlak

Pengamalan poligami yang demikian berdasarkan analisis lapangan yang menemukan bahwa poligami telah membuat perpecahan dalam kelurga. Pendapat ini banyak dianut oleh para pemikir islam kontemporer, berdasarkan ilmu-ilmu sosial dan humaniora yang dibuktikan dengan penelitian secara empirikal.

\section{Penutup}

Setelah memandang berbagai argumen yang dikemukakan para ahli Islam, bahwa ayat 3 surat An-Nisa merupakan ayat yang 
maknanya sangat global ( $\mathrm{amm}$ ) dan masih membutuhkan kajiankajian baru. Akan tetapi kajian selanjutnya hendaknya tidak hanya dicukupkan dengan pemahaman nash yang hanya mengandalkan logika deduktif, akan tetapi juga perlu juga pengkajian lapangan yakni pengkajian secara induktif-Empirik sehingga menghasilkan kajian yang komprehensip dan holistik.

\section{Daftar Rujukan}

As-Sayrazi, Al-Muhazzab, (Darul Ihya, 1994), Juz.II, Bab. Nikah

As-Shona'i, Bada'i as Shona'i, (Beirut, Darul Kutub Al-Araby, 1996), Juz 2

Abdul Wahab Khalaf, Ilmu Ushul Figh,(Indonesia, Haromain, 2003)

Atho Muzhar, Hukum Keluarga Di Dunia Islam Modern,(Jakarta, ciputat press, 2003)

As Syarakhsi, Al-Mabsut, (Beirut, Darul kutub Alamiyah, 1993), juz VI Abdurrahman Al-Jaziri, Al-Fiqh A'la Mazahib Al-Arba'ah, (tt.tt.tt), juz. IV

Fadlurrahman, Islam Mengangkat Martabat Wanita, (Gresik, Putra Pelajar, 1999)

Islam dan modernity transformation of an intellectual tradition, (Chicago, Chicago press, 1984 )

Ibnu Qudamah, Al-Mugni,(tt,tt,tt), Juz 5

Ibrahim Hosen, Figh Perbandingan Masalah Pernikahan, (Jakarta, Pustaka Firdaus, 2003), Bagian 1

J.N.D Anderson, Hukum Islam di Dunia Modern,(Surabaya, Amarpress,1991)

Khairuddin Nasution, Status Wanita di Asia Tenggara: Studi Terhadap Perundang-Undangan Perkawinan Indonesia dan Malaysia, ( INIS ,2002)

, Pengantar Studi Islam,(Yogyakarta, Academia Tazaffa, 2010), edisi Revisi

Muhammad Rasyid bin Ali Ridha, Tafsir Al-Manar, (mesir, 2002), Juz IV

Muhammad Idris As-Syafi'i, Al-Umm, (tt,tt,tt) Juz 5.

PSW IAIN SUNAN KALIJAGA, Islam dan kontekstualisasi seksualitas, (yogyakarta, Pustaka Pelajar, 2002)

Wahbah Az-Zuhaili, Figh Islam Wa Adillatuhu,(Beirut, Darul Fikr, 1985 ), Juz VII 
Status Poligami Dalam Perundang-Undangan Konvensional dan Kontemporer Serta Relevansinya Dengan Surat An-Nisa' Ayat 3 